\title{
Numerical Assessment of Squeezed Branch Pile in Silty Clay Soil
}

\author{
R. P. Bhujade, A. I. Dhatrak, S. W. Thakare
}

\begin{abstract}
Squeezed Branch Pile is derived on the basis of caste in place concrete pile. It has one or more branches along the pile shaft at design depth. Squeezed branch piles are often used in high rise building, transmission tower and in other pile foundations where anticipated uplift or vertical load may cause failure. This pile is one of the excellent options of pile foundation for soft soil and silty soil. The behaviour of Squeezed Branch pile is difficult to explain using simple pile-soil theories or two dimensional numerical analyses because of complicated geometry of pile.In the present numerical analysis, a $3 D$ pile-soil model of conventional circular pile and squeezed branch pile foundations are analysed using MIDAS GTS NX finite element software to find out effectiveness of squeezed branch pile over conventional pile. The aim is to study the performance of Squeezed Branch Pile foundation in silty clay with respect to various parameters such as types of loading, branch diameter, branch spacing and number of branches. Analysis shows that the squeezed branch pile has higher vertical, lateral and uplift load capacity as compared to conventional pile.
\end{abstract}

Keywords- Squeezed branch pile, ultimate load capacity, MIDAS GTS NX software, Vertical and Uplift loading.

\section{INTRODUCTION}

Pile foundation is considered as one of the widely used foundation technique when it comes to soft soil, which has huge problem of low bearing capacity, excessive and differential settlement. The squeezed branch pile is developed from conventional circular pile, it has one or more enlarged part (branch) along the pile shaft.Based on conventional intellection, many new techniques of pile foundation have been developed by changing cross section of conventional pile, providing multi-section to pile for more efficient foundation at lower cost. The squeezed branch pile is construction modification ofpile in which cavities for branches is formed by tightly squeezing of surrounding soil laterally without digging the soil. It achieves pile capacities more than that of conventional piles. The branches of pile not only increase the surface area of pile but also utilises the soil present around and under the branches to transmit the load. Squeezed branch pileeffectively decreases the settlement and cost of construction of pile because of unique load sharing mechanism Full scale field load test was carried out on squeezed branch pile to determine the bearing capacity and interaction law between soil and pile.Load shared by branch

Revised Manuscript Received on April, 252020.

* Correspondence Author

Dr. A. I. Dhatrak*, Associate Professor, Department of Civil Engineering, Government College of Engineering, Amravati, India.

R. P. Bhujade Department of Civil Engineering, Sant Gadge Baba Amravati, University, India.

S. W. Thakare, Associate professor, Department of civil Engineering, Government college of Engineering, Jalgaon, India.

(c) The Authors. Published by Blue Eyes Intelligence Engineering and Sciences Publication (BEIESP). This is an open access article under the CC BY-NC-ND license (http://creativecommons.org/licenses/by-nc-nd/4.0/) and plates were greater than that of the straight part and pile toe [1]. Applied bearing force was first shared by first disk. Once it reached to maximum limit the remaining load was shifted to second disk to compensate and balance the actionof load [2]. The three-dimensional numerical analysiswas conducted on squeezed branch pile to evaluate bearing responses of squeezed branch pile[3,4]. From the study it was concluded that as the distance of plate position increased from top, the lateral bearing capacity of pile was reduced.

\section{METHODOLOGY}

The behaviour of conventional circular pile and squeezed branch pile was analysed using MIDAS GTS NX finite element software. To govern the soil behaviour, soil was modelled as Mohr-coulomb model. The pile was modelled as a linearly elastic perfectly plastic model. The dimensions of soil model were $100 \mathrm{~m} \times 100 \mathrm{~m} \times 100 \mathrm{~m}$. The geometry of three-dimensional model of pile and section of squeezed branch pile considered for analysis is shown in Fig 1. The properties assigned to pileand soil are shown in following Table I and II respectively.

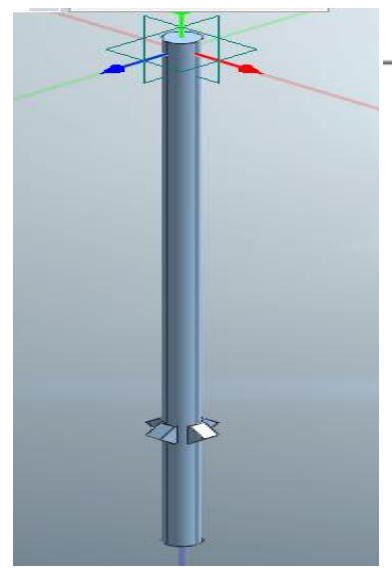

(a)

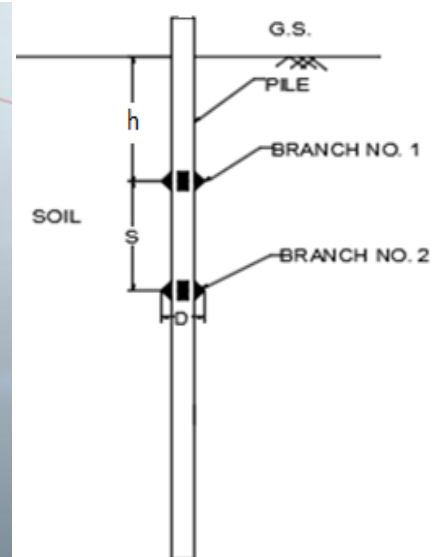

(b)
Fig.1: (a) The three-dimensional view of squeezed branch pile, (b) Schematic diagram of squeezed branch pile for proposed analysis

Table I: Properties assigned to the pile

\begin{tabular}{|c|l|c|c|c|}
\hline Sr. No. & \multicolumn{1}{|c|}{ Properties } & Symbol & Values & Units \\
\hline 1 & Young's modulus & E & 27386127 & $\mathrm{kN} / \mathrm{m}^{2}$ \\
\hline 2 & Poisson's ratio & $\boldsymbol{v}$ & 0.2 & - \\
\hline 3 & Density & $\boldsymbol{\gamma}$ & 24 & $\mathrm{kN} / \mathrm{m}^{3}$ \\
\hline
\end{tabular}

\section{NUMERICAL ANALYSIS}

Published By:

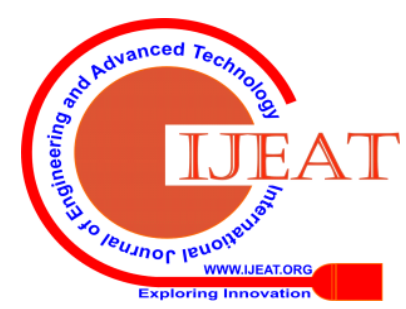


The analysis was conducted on a three-dimensional finite element model pile foundation. Analysis was carried out to evaluate the performance of squeezed branch pile and conventional circular pile embedded in silty clay. The varied parameters were types of loading, branch diameter, branch spacing and number of branches. Shaft diameter and length of pile were kept constant.Details of parameters selected for analysis is given in Table III.

Table II: Properties assigned to the soil [7]

\begin{tabular}{|l|c|c|c|c|c|}
\hline Properties & Unit weight & Young's modulus & Poisson's ratio & Angle of internal friction & Cohesion \\
\hline Symbol & $\gamma$ & $\mathbf{E}$ & $\mathbf{Y}$ & $\boldsymbol{\emptyset}$ & $\mathbf{C}$ \\
\hline Unit & $\mathrm{kN} / \mathrm{m}^{3}$ & $\mathrm{kPa}$ & - & Degree & $\mathrm{KPa}$ \\
\hline Silty clay & 18 & 20000 & 0.4 & 20 & 22 \\
\hline
\end{tabular}

Table III: Details of constant and varying parameters

\begin{tabular}{|c|l|c|l|}
\hline $\begin{array}{c}\text { Sr. } \\
\text { No. }\end{array}$ & \multicolumn{1}{|c|}{ Details of Parameter } & $\begin{array}{c}\text { Constant } \\
\text { Parameter }\end{array}$ & Varying Parameter \\
\hline 1 & Length of pile (L) & $15 \mathrm{~m}$ & \\
\hline 2 & Diameter of shaft (d) & $0.7 \mathrm{~m}$ & \\
\hline 3 & Length of branch (l) & $0.7 \mathrm{~m}$ & \\
\hline 4 & Width of branch (b) & $0.35 \mathrm{~m}$ & \\
\hline 5 & Type of Loading & - & $\begin{array}{l}\text { i. Vertical Loading } \\
\text { ii. Lateral Loading } \\
\text { iii. Uplift Loading }\end{array}$ \\
\hline 6 & Number of Piles (N) & - & $\begin{array}{l}\text { i. Single pile } \\
\text { ii. Pile group with 3, 4, 5 and 6 piles }\end{array}$ \\
\hline 7 & Branch Position ratio (h / L) & - & 0.20, 0.38, 0.56, 0.74, 0.92 \\
\hline 8 & Branch Spacing ratio (S / D) & - & $1.5,2,2.5,3,3.5$ \\
\hline 9 & Branch Diameter ratio (D/d) & - & $1.5,2,2.5,3$ \\
\hline 10 & Branch Number & - & $1,2,3$ \\
\hline 11 & Spacing between piles (s) & - & $3 \mathrm{D}$ \\
\hline
\end{tabular}

\section{RESULTS AND DISCUSSION}

The analysis was conducted on single squeezed branch pile and conventional circular pile subjected to vertical load, uplift load and lateral load in silty clay. The load settlement /displacement curves for conventional circular pile, squeezed branch pile with different branch diameter, branch position, branch spacing and number of branches are shown in Fig 1 to Fig 6 respectively. The ultimate load capacity for conventional pile and squeezed branch pile are taken as per provision of IS: 2911 (Part -4) 1985.

The ultimate vertical, lateral and uplift load capacities of conventional circular pile is given in Table IV. A load settlement / displacement curve for conventional circular pile subjected to vertical load isshown in Fig. 2.

Table IV: Ultimate load capacities of conventional pile

\begin{tabular}{|c|c|}
\hline Type of Loading & Ultimate load capacity $(\mathrm{kN})$ \\
\hline Vertical Loading & 1481 \\
\hline
\end{tabular}

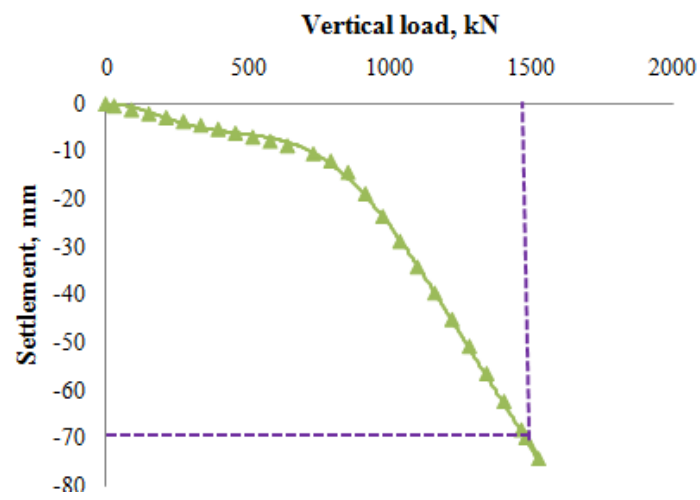

Fig. 2: Load settlement curve for conventional pile subjected to Vertical load

Ultimate vertical load capacities of squeezed branch pile with different branch diameters are shown in Table V.Fig. 3 showsload settlement curves for squeezed branch pile with different branch diameters.

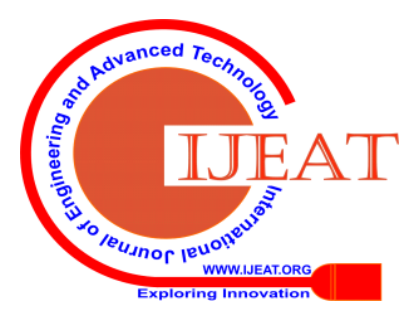


Table V: Ultimate Vertical Load Capacities of squeezed branch pile with different branch diameter ratio

\begin{tabular}{|c|c|c|c|}
\hline Branch diameter ratio & $\mathrm{D} / \mathrm{d}=1.5$ & $\mathrm{D} / \mathrm{d}=2$ & $\mathrm{D} / \mathrm{d}=2.5$ \\
\hline $\begin{array}{c}\text { Ultimate Vertical load } \\
\text { capacity }(\mathrm{kN})\end{array}$ & 2577 & 2814 & 3193 \\
\hline
\end{tabular}

Load, $\mathrm{kN}$

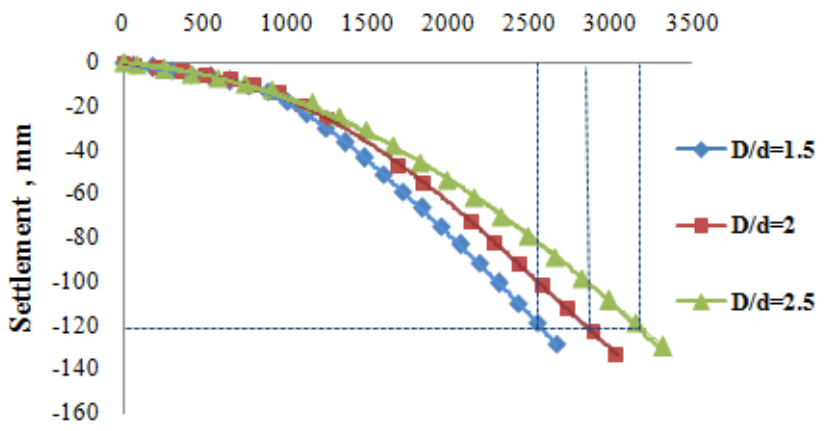

Fig. 3: Load settlement curve for squeezed branch pile with different branch diameters

From the above results, it was observed that the ultimate load capacity of squeezed branch pile increased with the increase in branch diameter. The maximum ultimate load capacity of squeezed branch pile was obtained at the branch diameter ratio equal to $(\mathrm{D} / \mathrm{d})=2.5$.

Ultimate vertical load capacities of squeezed branch pile with different branch positions are shown in Table VI.Fig. 4 showsload settlement curves for squeezed branch pile with different branch positions.

Table VI: Ultimate Vertical Load Capacities of squeezed branch pile with different branch positions

\begin{tabular}{|c|c|}
\hline Position ratio & Ultimate Vertical load capacity (kN) \\
\hline $\mathrm{h} / \mathrm{L}=0.20$ & 3195 \\
\hline $\mathrm{h} / \mathrm{L}=0.37$ & 3198 \\
\hline $\mathrm{h} / \mathrm{L}=0.54$ & 3307 \\
\hline $\mathrm{h} / \mathrm{L}=0.70$ & 3400 \\
\hline $\mathrm{h} / \mathrm{L}=0.87$ & 2888 \\
\hline
\end{tabular}

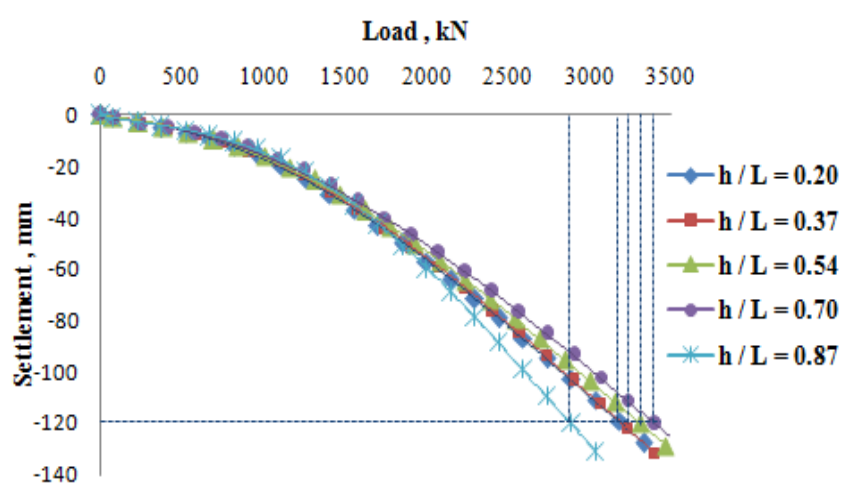

Fig. 4:Load settlement curve for squeezed branch pile with different branch positions

From the above results, it was observed that the ultimate load capacity of squeezed branch pile increased with the depth of branch position up to a certain point and decreases further. Therefore the maximum ultimate load capacity of squeezed branch pile was obtained at the branch position ratio equal to $\mathrm{h} / \mathrm{L}=0.70$.
Ultimate vertical load capacities of squeezed branch pile with different branch spacing are shown in Table VII.Fig. 5 showsload settlement curves for squeezed branch pile with different branch spacing.

Table VII:Ultimate vertical Load Capacities of squeezed branch pile with different branch spacing ratio

\begin{tabular}{|c|c|}
\hline $\begin{array}{c}\text { Branch spacing } \\
\text { ratio }\end{array}$ & $\begin{array}{c}\text { Ultimate Vertical load capacity } \\
(\mathrm{kN})\end{array}$ \\
\hline $\mathrm{S} / \mathrm{D}=2.0$ & 3386 \\
\hline $\mathrm{S} / \mathrm{D}=2.5$ & 3430 \\
\hline $\mathrm{S} / \mathrm{D}=3.0$ & 4157 \\
\hline $\mathrm{S} / \mathrm{D}=3.5$ & 3647 \\
\hline
\end{tabular}

\section{Load, $\mathrm{kN}$}

$0 \quad 500 \quad 1000150020002500300035004000 \quad 4500$

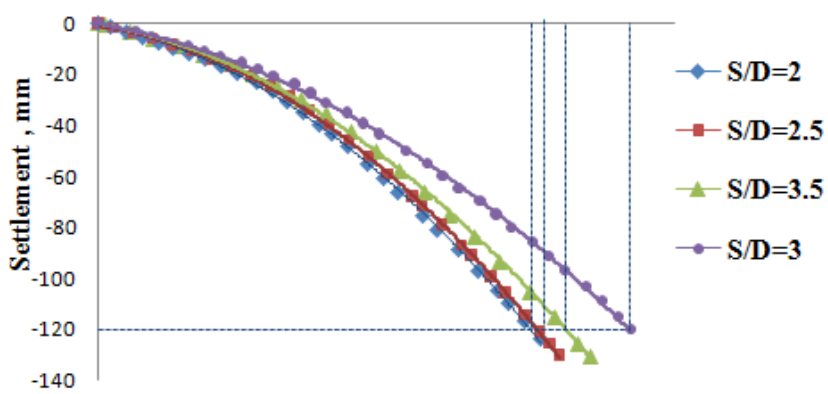

Fig. 5:Load settlement curve for squeezed branch pile with different branch spacing

From the above results, it was observed that the vertical load capacity of squeezed branch pile increased with increase in branch spacing between two branches up to branch spacing ratio $\mathrm{S} / \mathrm{D}=3$, after that ultimate load capacity reduced with further increase in branch spacing. Therefore, analysis of group of double branch squeezed branch piles for ultimate load capacities, pullout capacities and lateral capacities were carried out by keeping spacing ratio S / D = 3 constant. Ultimate vertical load capacities of squeezed branch pile with different branch spacing shown in table VIII.Fig. 6 showsload settlement curves for squeezed branch pile with different number of branch.

Table VIII: Ultimate vertical Load Capacities of squeezed branch pile with different number of branch

\begin{tabular}{|c|c|}
\hline Number of branches & Ultimate Vertical load capacity $(\mathrm{kN})$ \\
\hline Single branch & 3400 \\
\hline Double branch & 4157 \\
\hline Triple branch & 3427 \\
\hline
\end{tabular}

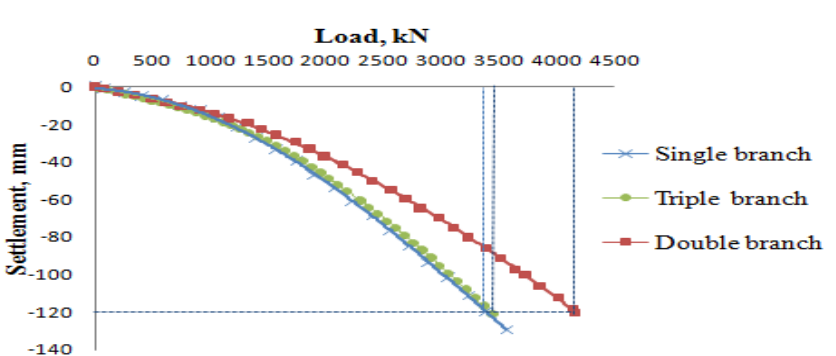

Fig. 6:Load settlement curve for squeezed branch pile with different number of branches

Published By:

Blue Eyes Intelligence Engineering

\& Sciences Publication

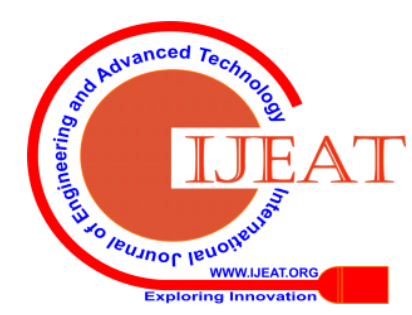


The ultimate load carrying capacity of double branch pile was more than that of single branch pile and triple branch pile when compared to conventional circular pile of same surface area. Vertical, lateral and uplift load analysis were also carried out on squeezed branch pile and conventional circular pile with number of piles equal to 3 (in triangular arrangement), 4 (in square arrangement), 5 ( in pentagonal arrangement and square arrangement with one pile at centre), 6 ( in hexagonal arrangement and two row arrangement ). Table IX shows the ultimate load capacities of group of conventional circular pile and squeezed branch pile.

Ultimate capacities of group of conventional circular pile and squeezed branch pile are represented in the form of bar charts as shown in Fig. 7.

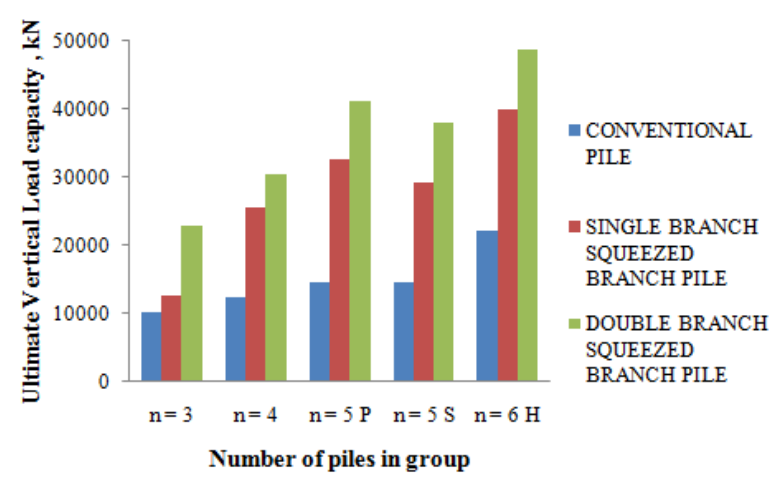

(a)

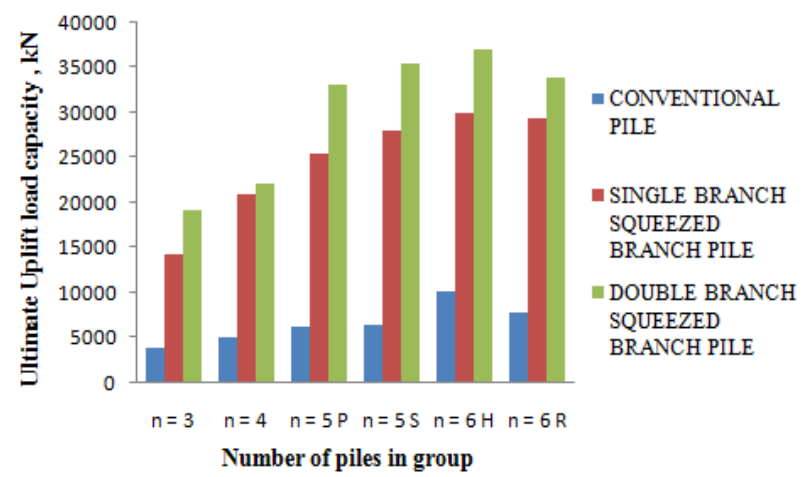

(b)

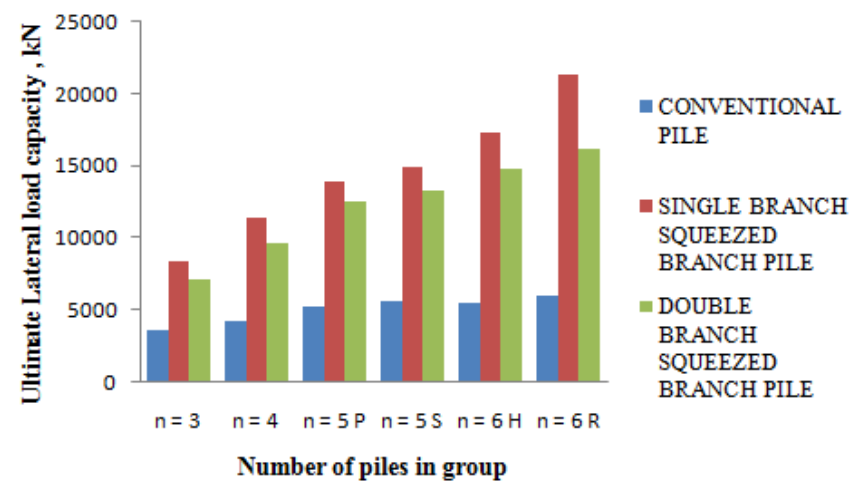

(c)

Fig.7: Ultimate load capacities of squeezed branch pile groups with different numbers of piles in group (a) Ultimate vertical load capacities, (b) Ultimate uplift load capacities, and (c) Ultimate lateral load capacities

Table IX: Ultimate load capacities of group of conventional circular pile and squeezed branch pile under different conditions

\begin{tabular}{|c|c|c|c|c|c|c|c|c|c|}
\hline \multirow[b]{2}{*}{$\begin{array}{l}\text { Types of pile } \\
\text { group }\end{array}$} & \multicolumn{3}{|c|}{$\begin{array}{l}\text { Ultimate load capacity } \\
\qquad(\mathrm{kN})\end{array}$} & \multicolumn{3}{|c|}{ Ultimate uplift load capacity $(\mathrm{kN})$} & \multicolumn{3}{|c|}{$\begin{array}{l}\text { Ultimate lateral load capacity } \\
\qquad(\mathrm{kN})\end{array}$} \\
\hline & $\begin{array}{l}\text { Circular } \\
\text { pile }\end{array}$ & $\begin{array}{c}\text { Single } \\
\text { branch } \\
\text { squeezed } \\
\text { branch } \\
\text { pile } \\
\end{array}$ & $\begin{array}{c}\text { Double } \\
\text { branch } \\
\text { squeezed } \\
\text { branch } \\
\text { pile } \\
\end{array}$ & $\begin{array}{l}\text { Circular } \\
\text { pile }\end{array}$ & $\begin{array}{c}\text { Single } \\
\text { branch } \\
\text { squeezed } \\
\text { branch } \\
\text { pile } \\
\end{array}$ & $\begin{array}{c}\text { Double } \\
\text { branch } \\
\text { squeezed } \\
\text { branch } \\
\text { pile } \\
\end{array}$ & $\begin{array}{l}\text { Circular } \\
\text { pile }\end{array}$ & $\begin{array}{c}\text { Single } \\
\text { branch } \\
\text { squeezed } \\
\text { branch } \\
\text { pile }\end{array}$ & $\begin{array}{c}\text { Double } \\
\text { branch } \\
\text { squeezed } \\
\text { branch } \\
\text { pile } \\
\end{array}$ \\
\hline $\begin{array}{l}\mathrm{n}=3 \text { (triangular } \\
\text { arrangement) }\end{array}$ & 10257 & 12051 & 22950 & 3994 & 14262 & 19312 & 3475 & 8323 & 7090 \\
\hline $\begin{array}{l}\mathrm{n}=4 \text { (square } \\
\text { arrangement) }\end{array}$ & 12386 & 25416 & 30343 & 5180 & 20939 & 22215 & 4210 & 11391 & 9597 \\
\hline $\begin{array}{c}\mathrm{n}=5 \text { ( } 4 \text { at } \\
\text { corner and } 1 \text { at } \\
\text { centre) }\end{array}$ & 14511 & 32473 & 41159 & 6397 & 28109 & 35465 & 5524 & 14879 & 13254 \\
\hline $\begin{array}{c}\mathrm{n}=5 \\
\text { (pentagonal } \\
\text { arrangement) }\end{array}$ & 14443 & 29191 & 37965 & 6248 & 25447 & 33170 & 5174 & 13834 & 12526 \\
\hline $\begin{array}{c}\mathrm{n}=6 \\
\text { (hexagonal } \\
\text { arrangement) }\end{array}$ & 22055 & 39792 & 48565 & 10222 & 30005 & 37111 & 5455 & 17311 & 14783 \\
\hline $\begin{array}{l}\mathrm{n}=6 \text { (in } 2 \text { row } \\
\text { arrangement) }\end{array}$ & 16810 & 36543 & 43135 & 7919 & 29408 & 33924 & 5935 & 21369 & 16131 \\
\hline
\end{tabular}


From the results, it was observed that the ultimate vertical load capacity increased with increase in number of piles in group. Vertical and uplift load carrying capacity of double branch squeezed branch pile groups were more as compared to the single branch squeezed branch pile groups. Lateral load carrying capacity of single branch squeezed branch pile groups were more as compared to the double branch squeezed branch pile groups.

Table X: Percentage increase in pile capacity compared with conventional circular pile

\begin{tabular}{|c|c|c|c|c|c|c|}
\hline \multirow{2}{*}{$\begin{array}{l}\text { Types of pile } \\
\text { groups }\end{array}$} & \multicolumn{2}{|c|}{$\begin{array}{l}\text { \% increase in ultimate load } \\
\text { capacity }\end{array}$} & \multicolumn{2}{|c|}{$\begin{array}{l}\text { \% increase in ultimate uplift } \\
\text { load capacity }\end{array}$} & \multicolumn{2}{|c|}{$\begin{array}{l}\text { \% increase in ultimate lateral } \\
\text { load capacity }\end{array}$} \\
\hline & $\begin{array}{l}\text { Single branch } \\
\text { squeezed } \\
\text { branch pile }\end{array}$ & $\begin{array}{l}\text { Double branch } \\
\text { squeezed } \\
\text { branch pile }\end{array}$ & $\begin{array}{l}\text { Single branch } \\
\text { squeezed } \\
\text { branch pile }\end{array}$ & $\begin{array}{l}\text { Double branch } \\
\text { squeezed } \\
\text { branch pile }\end{array}$ & $\begin{array}{l}\text { Single branch } \\
\text { squeezed } \\
\text { branch pile }\end{array}$ & $\begin{array}{l}\text { Double branch } \\
\text { squeezed } \\
\text { branch pile }\end{array}$ \\
\hline $\begin{array}{l}\mathrm{n}=3 \text { (triangular } \\
\text { arrangement) }\end{array}$ & 23 & 123 & 257 & 384 & 139 & 104 \\
\hline $\begin{array}{l}\mathrm{n}=4 \text { (square } \\
\text { arrangement) }\end{array}$ & 105 & 145 & 304 & 329 & 170 & 128 \\
\hline $\begin{array}{l}\mathrm{n}=5 \text { (pentagonal } \\
\text { arrangement) }\end{array}$ & 102 & 163 & 307 & 431 & 167 & 142 \\
\hline $\begin{array}{l}n=5 \text { ( } 4 \text { at corner } \\
\text { and } 1 \text { at centre) }\end{array}$ & 124 & 184 & 339 & 454 & 169 & 142 \\
\hline $\begin{array}{l}\mathrm{n}=6 \text { (hexagonal } \\
\text { arrangement) }\end{array}$ & 104 & 137 & 194 & 263 & 217 & 146 \\
\hline $\begin{array}{l}\mathrm{n}=6 \text { (in } 2 \text { row } \\
\text { arrangement) }\end{array}$ & 137 & 157 & 271 & 320 & 260 & 172 \\
\hline
\end{tabular}

Table $\mathrm{X}$ shows the percentage increase in ultimate load capacities of group of squeezed branch pile compared with groups of conventional circular pile. Percentage increase in ultimate capacities of group of squeezed branch pile compared with conventional circular pile groups are represented in the form of bar charts as shown in Fig 8.

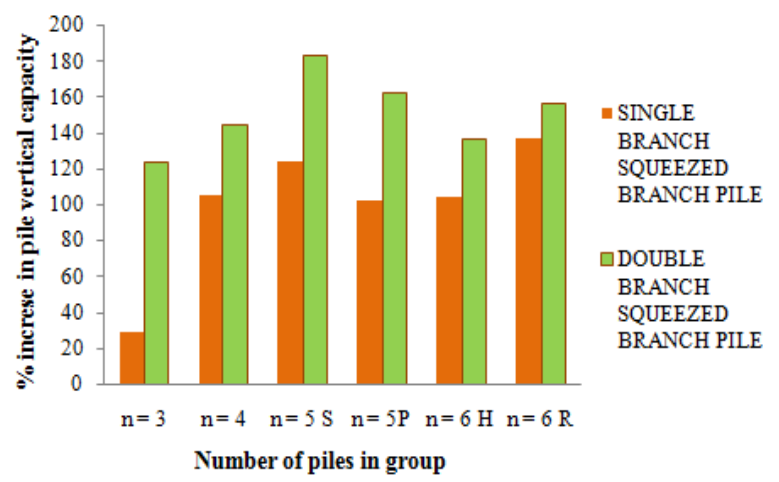

(a)

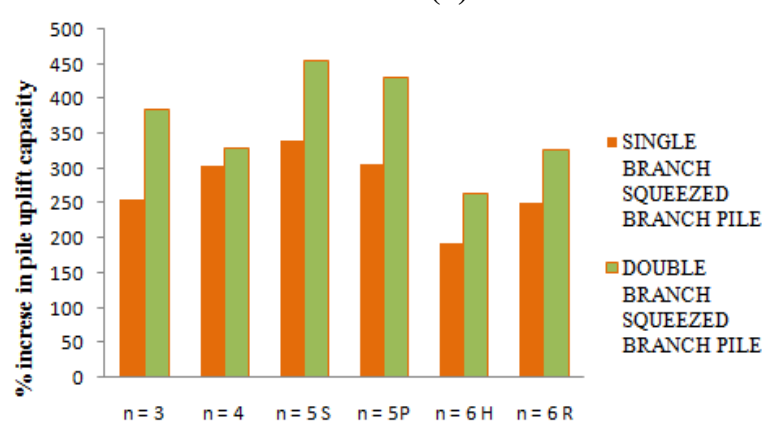

Number of piles in group

(b)

Retrieval Number: C6624029320/2020@BEIESP DOI: 10.35940/ijeat.C6624.049420

Journal Website: www.ijeat.org

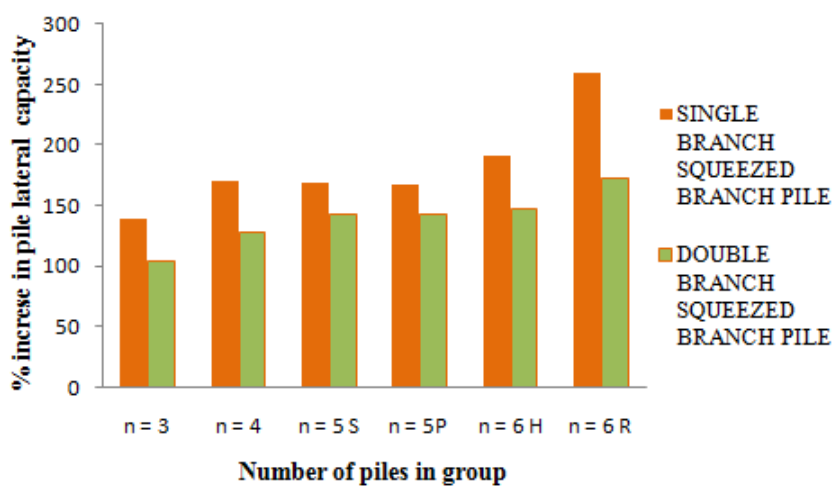

(c)

Figure 8: Percentage Increment in (a) Ultimate load capacities of squeezed branch pile group with number of piles in the group, (b) Ultimate uplift load capacities of squeezed branch pile group with number of piles in the

group, and (c) Ultimate lateral load capacities of squeezed branch pile group with number of piles in the group

\section{CONCLUSIONS}

Based on the results of the present study, the following conclusions are drawn:

1. The ultimate load carrying capacity of squeezed branch increases with increase in diameter of branch of pile.

Published By:

Blue Eyes Intelligence Engineering

\& Sciences Publication

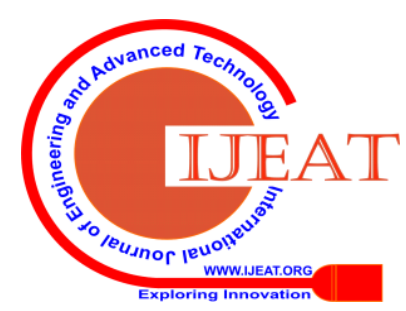


2. In case of single branch pile, as the branch depth from the top of soil increases its ultimate load capacity also increases.

3. The vertical load carrying capacity of double branch squeezed branch pile is much higher as compared to those of single branch squeezed branch pile and triple branch squeezed branch pile (up to181\%).

4. Ultimate vertical load and Uplift load carrying capacity of double branch squeezed branch pile groups are more as compared to the single branch squeezed branch pile groups.

5. In case of double branch pile, as the spacing between pile increases the ultimate load carrying capacity increases up to the branch spacing ratio S/ $\mathrm{D}=3$, after that with further increase in the branch spacing ultimate load carrying capacity reduces. The optimum S / D = 3 may be adopted.

6. The percentage increase in ultimate load capacity of single branch squeezed branch pile group of six piles in 2 row arrangement is more as compared to conventional circular pile group (up to137\%).

7. The percentage increase in ultimate load capacity of double branch squeezed branch pile group of five piles in square arrangement with one pile at centre is more as compared to conventional circular pile group (up to184\%).

8. The percentage increase in ultimate uplift capacity of single branch squeezed branch pile and double branch squeezed branch pile group of 5 piles in square arrangement with one pile at centre is more as compared to the conventional circular pile.

9. The percentage increase in ultimate lateral load capacity of single branch squeezed branch pile and double branch squeezed branch pile group of six piles in 2 row arrangements is more as compared to the conventional circular pile.

\section{REFERENCES}

1. GAO Xiao-juan, WANG Jin-chan and ZHU Xiang-rong,"Static load test and load transfer mechanism study of squeezed branch and plate pile in collapsible loess foundation",Journal of Zhejiang University SCIENCE AISSN, 1673-565X,2007, pp.1110-1117.

2. D. Qian, C. Sun and D. Wang, "Study between squeezed branch pile and soil”, foundation analysis and design,@ASCE, 2006, pp. 218225.

3. Minxia Zhang, Ping $\mathrm{Xu}$,Wenjie Cui and Youbin Gao, "Bearing behaviour and failure mechanism of squeezed branch piles",Journa of Rock Mechanics and Geotechnical Engineering,2018, pp.935-946.

4. Xiaojuan GAO, Yuehui L, "Numerical Simulation of Squeezed Branch and Plate Pile subjected to Vertical and Lateral Loads", Advanced Materials Research Vols 926-930, 2014, pp. 597-600.

5. LianzhongYin, Xiaoguang Fan and Songjiang Wang, "study on application of squeezed branch pile in clay soil foundation", 3rd International Conference on Energy Materials and Environment Engineeringdoi:10.1088/1755-1315/61/1/012091, 2017, pp.1-6.

6. Weifeng Han BinbinFeng Jing Zhou ChenyuanLu, "The study on the engineering properties of squeezed branch piles under combined load",Applied Mechanics and Materials, Vols. 580-583, 2014, pp.371-375.

7. SONG Shitong, XU Chao, "Numerical Analyses of Soil Arching in Rigid Pile Supported Embankments", Ground Improvement and Geosynthetics,@ASCE,2014, PP.49-56.

8. "Indian Standard Code of Practice for Design and Construction of Pile Foundation", IS code 2911 (Part-IV)-1985.

9. Dr. A. I. Dhatrak, MaithilyGhawde and Prof. S. W. Thakare, "Experimental study on Belled Wedge Pile for different loadings in cohesionless soil", Indian Geotechnical Conference, Indian Institute of Science Bengaluru, 2018, pp.1-7.
10. N. G. Tale, Dr. A. I. Dhatrak, Prof. S. W. Thakare, "Numerical Analysis of Spin Fin Pile under Different Loading Conditions", International Journal of Technical Innovation in Modern Engineering \& Science (IJTIMES), Volume 5, Issue 05, e-ISSN: 2455-2585, 2019, pp.659-664.

11. Prof. S. W. Thakare, P. P. Wankhade, Dr. A. I. Dhatrak,"Experimental Investigations on Performance of Spin Fin Pile under Different Loading Modes",International Journal of Technical Innovation in Modern Engineering \& Science (IJTIMES), Volume 5, Issue 05, e-ISSN: 2455-2585, 2019, pp.501-506.

\section{AUTHOURS PROFILE}

Dr. A. I. Dhatrak is working as Associate Professor in Civil Engineering

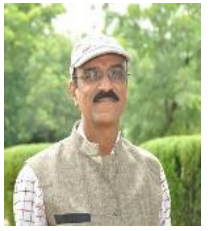
Department, and Dean Academics at Government College of Engineering, Amravati, India. With thirtyone year of experience, he has completed his Ph.D. in 2014. He has more than 90 publications in national and international journal and conferences. He has guided more than 40 students in their Post-Graduation dissertation in geotechnical Engineering. Currently he is guiding six Ph.D. student and thirteen master students in geotechnical engineering.

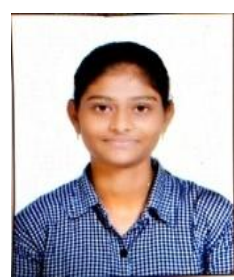

R. P. Bhujade has completed her Bachelor's degree in Civil Engineering from Sant Gadge Baba Amravati, University, India. Currently she is pursuing her Master Degree in Geotechnical Engineering at Government College of Engineering, Amravati, India.

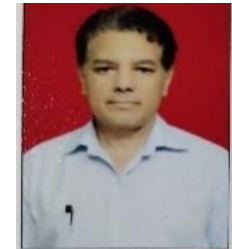

S. W. Thakare is working as Associate professor in Department of civil Engineering, Government college of Engineering, Jalgaon, India. Currently with thirty-two years of experience, he is pursuing his Ph.D. in "Evaluation of capacities of Barrette Pile Foundation in Sandy soil" at Government college of Engineering, Amravati, India. He has published 40 research paper in various national and international journals and conferences. He has guided about 40 students for their Post-Graduation dissertation in Geotechnical Engineering.

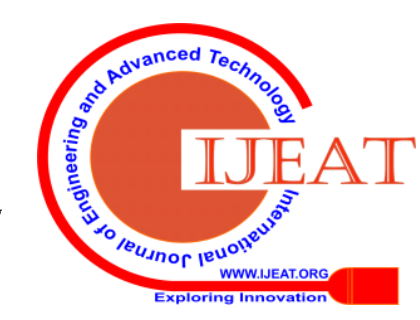

